\title{
A new method to exfoliate Graphite oxide and application for synthesis Graphene by chemical method
}

- Mai Thanh Tam

- Ha Thuc Chi Nhan

- Ha Thuc Huy

University of Science, VNU - HCM

(Received on March $20^{\text {th }} 2013$, accepted on Jannuary $16^{\text {th }} 2015$ )

ABSTRACT

A new method to separate graphite oxide (GO) modified by polyethylene oxide (PEO) by the aid of ultrasonic radiation was developed. Modified GO (graphene oxide or single layer of graphite oxide) did not show not appear crystalline peak $\left(d_{002}\right)$ on the $X$ Ray and took the form of a single layer graphene oxide on the image AFM and TEM.

The exfoliated graphene oxide was reduced (RGO) to graphene by the reducing agent system $\mathrm{HI}$ - Acetic acid ( $\mathrm{HI}-\mathrm{AcOH})$. The sheet resistance of $\mathrm{RGO}_{\mathrm{HI}-\mathrm{AcOH}}$ is about 120 $\Omega / s q$ in the form graphene paper. In addition, FTIR, UV-Vis and Raman spectra showed more clearly about characteristics of graphite

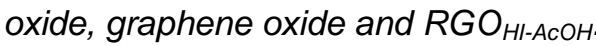

Keywords: Graphene, graphite oxide, graphene oxide, polyethylene oxide (PEO).

\section{INTRODUCTION}

Graphene can be made by many different ways as the mechanical exfoliation from graphite [4, 12, 14], chemical vapor deposition (CVD) [18] and reduction of graphene oxide $[2,7,8,16$, $17,19,21]$. In particular, graphene made from graphite oxide has many diverse applications in many different fields. Especially, the field of polymer nanocomposite is the most important. Graphite oxide (GO) was synthesized by oxidation of graphite with strong oxidizing agents as $\mathrm{KMnO}_{4}, \mathrm{KNO}_{3}, \mathrm{KClO}_{3}$ and others in the acid conditions [1]. The most common methods using redox $\mathrm{KMnO}_{4}, \mathrm{KNO}_{3}, \mathrm{H}_{2} \mathrm{SO}_{4}$ is Hummers [6]. Graphite oxide was attached to the surface of the polar groups such as hydroxyl, epoxy, carbonyl and carboxylic [1]. Based on these polar groups, the distance between two layers of graphite oxide is raised from $3.3 \AA$ to $8.0 \AA$ [1]. This is an opportunity to insert the modified compound in between the GO layers of and to exfoliate the layers of graphene oxide. Between the GO layers can be inserted into the compound with chemical or physical interactions. In the chemical interaction, isocyanate compound was used commonly because -NCO groups can react easily with the $-\mathrm{OH},-\mathrm{COOH}$ and epoxide groups on the graphite oxide [20]. However, if GO and modifier had interacted with each other, the reduction of the GO would become more difficult [1]. So, the exfoliated methods of the GO by surface-active compounds preferred to use more. The non-ionic surfactant which the 
structure interacted strongly with GO was used the modifier in this case. Polyethylene glycol (PEG) is a specific examples that our research team has used. Earlier, the PEG was grafted onto the GO with different bridge to apply in the fields of biology [10,11, 22, 23].

In this study, polyethylene glycol was used as not only a modified agent but also preliminary reduced agent for graphite oxide because it has the $\mathrm{OH}$ group as a reducing agent [2]. Then, the modified graphite oxide was exfoliated easily by the aid of ultrasonic radiation. The exfoliated graphite oxide is called graphene oxide. The graphene oxide is reduced by the reducing agent to form reduced graphene oxide (RGO). The reducing agent was use such as hydrazine $\left(\mathrm{NH}_{2-}\right.$ $\left.\mathrm{NH}_{2}\right)$ [5, 17, 21], sodium borohydride $\left(\mathrm{NaBH}_{4}\right)$ [16], alcohol [2], bacteria [3], thermal reduction (reduced by heat) $[8,15]$ and others. Conductivity of RGO depends heavily on the reduction and reducing agent. In this article, we used the same reduction as the group of In Kyu Moon but our group has reduced graphene oxide (graphite oxide modified by PEG) instead of graphite oxide as these authors.

\section{METERIALS AND METHODS}

\section{Materials}

Graphite flake were purchased from Sigma Aldrich and did not use further purification. Sulfuric acid (95-97 wt\%), hydrogen peroxide (30 wt\%), potassium permanganate, sodium nitrate, hydroiodic acid (57 wt\%), sodium bicarbonate, acetic acid were obtained from commercial sources and used as received. Preparation of graphite oxide. Graphite oxide was prepared from graphite flake using the modified Hummers and Offemman's method with sulfuric acid, sodium nitrate and potassium permanganate [6]. Accordingly, $10 \mathrm{~g}$ graphite, $0.5 \mathrm{~g} \mathrm{NaNO}_{3}, 230 \mathrm{ml}$ of $\mathrm{H}_{2} \mathrm{SO}_{4}(98 \%)$ were placed in $2500 \mathrm{ml}$ four-neck-flask. The mixture was stirred and cooled at $0{ }^{\circ} \mathrm{C}$. Then, $300 \mathrm{~g}$ of $\mathrm{KMnO}_{4}$ was added slowly to the system (keeping the temperature of the suspension system at 20 $\left.{ }^{\circ} \mathrm{C}\right)$. The next, the temperature of the system was raised to $35 \pm 2{ }^{\circ} \mathrm{C}$ for 30 minutes to the oxidation of graphite. Then, the reactor was diluted with $460 \mathrm{ml}$ of distilled water and raised to $98{ }^{\circ} \mathrm{C}$ for 15 minutes. The end of 15 minutes, the suspension system continue to be diluted with $1400 \mathrm{ml}$ of distilled water and $500 \mathrm{ml} \mathrm{H}_{2} \mathrm{O}_{2}(30$ wt\%) was added to the mixture to remove residual $\mathrm{KMnO}_{4}$ and other impurities. After treatment with peroxide, the reaction mixture with bright yellow was observed. Finally the product $(\mathrm{GO})$ was centrifuged, washed several times with acetone and dried in vacuum at $80{ }^{\circ} \mathrm{C}$.

\section{Modification of graphite oxide}

Graphite oxide modified polyethylene glycol (PEG) with a molecular weight of 1500 $\mathrm{g} / \mathrm{mol}$. Accordingly, $1.0 \mathrm{~g}$ of GO was dispersed in one liter of distilled water in the beaker by ultrasound waves (ultrasonic UP400S - Germany with a standard aluminium horn with replaceable tip diameter of $13 \mathrm{~mm}$ ) for 30 minutes. Then, the suspension of GO was transferred to the 1.5-liter flask and added to $5.0 \mathrm{ml}$ of solution $\mathrm{NH}_{3}$ (35wt.\%). In addition, $10.0 \mathrm{~g}$ PEG was added and stirred with a mechanical stirrer for 24 hours. The modified graphite oxide (MGO) was then split into single-layer graphene oxide under the effect of ultrasound within 1 hour. Finally, the product was deposited with solution of $\mathrm{HCl} 5 \mathrm{wt} . \%$, then filtered by vacuum and washed several times with a mixture of acetone-water (50/50). Obtained MGO was a wet powder form and used to continue the process of reducing that followed 
(except when necessary to analyze the property of MGO).

\section{Reduction of MGO by HI-AcOH system}

The reduction process was done similar way as In Kyu Moon [13]. Accordingly, $2.0 \mathrm{~g}$ of MGO was dispersed in $750 \mathrm{ml}$ acetic acid $(1000 \mathrm{ml}$ three-neck-flask) and sonicated by a LT-60H ultrasonic bath cleaner $(35 \mathrm{kHz})$ for 1 hour. Then, $40 \mathrm{ml}$ iodic acid (HI) was added and continued to sonicated for 30 minutes at $40^{\circ} \mathrm{C}$. The mixture was stirred at $40{ }^{\circ} \mathrm{C}$ for 40 hour. The product was filtered and washed with sodium bicarbonate solution (5 wt.\%) $(5 \times 50 \mathrm{ml})$, distilled water $(5 \times 50 \mathrm{ml})$ and acetone $(2 \times 50 \mathrm{ml})$. Then, It was dried under vacuum at $80{ }^{\circ} \mathrm{C}$ for 12 hours and the weight of $\mathrm{RGO}_{\mathrm{HI}-\mathrm{AcOH}}$ after purifying was $1.5 \mathrm{~g}$ (accounted for $75 \mathrm{wt} \%$ compared with MGO).

\section{Characterizations}

\section{RESULTS AND DISCUSSION}

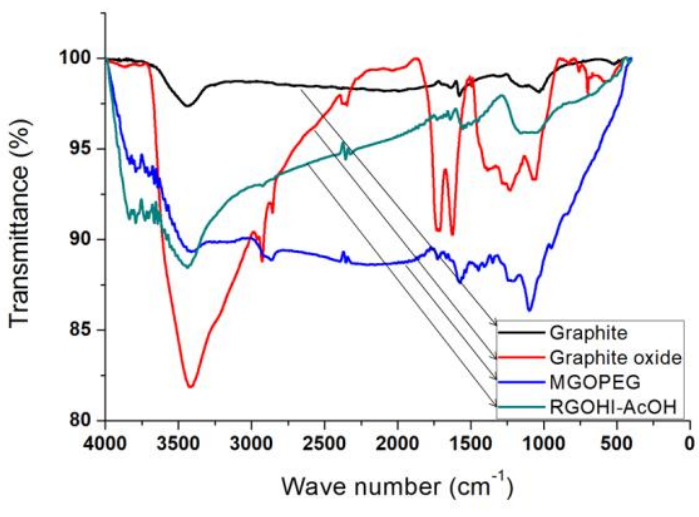

The morphology of the graphene were examined by high resolution transmission electron microscopy (JEOL, model JEM-1400) and AFM (Dimension 3100, Veeco) using a silicon cantilever operated in the tapping mode at room temperature. The spectroscopic analyses were carried out using a Fourier transform infrared spectrometer (Equinox 55) and Raman spectrometer (Horiba Jobiny, laser at $632 \mathrm{~nm}$ ). The thermal properties of $\mathrm{GO}, \mathrm{RGO}_{\mathrm{HI}-\mathrm{AcOH}}$ and MGO were carried out using TGA Q500 from room temperature to $600{ }^{\circ} \mathrm{C}$, at a rate of 20 ${ }^{\circ} \mathrm{C} /$ minutes in the continuous nitrogen flow. The sheet resistance (Rs) of the composite films was measured using a 4-point probe resist meter (CTM-100 MP, Advanced instrument Technology).

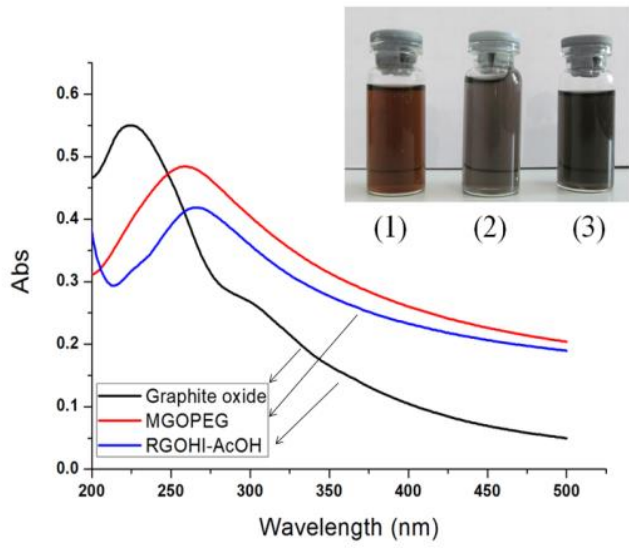

B

Figure 1. FTIR (A) and UV-Vis spectra (B) of graphite, graphite oxide (GO), modified graphite oxide (MGO) and RGOHI-AcOH [(1)- GO in water (1,0 mg/ $100 \mathrm{ml} \mathrm{H2O})$, (2)- MGO in water (1,0 mg/ $100 \mathrm{ml} \mathrm{H2O})$, (3)- RGOHIAcOH in solution of SDS 0.5 wt. $\%(1,0 \mathrm{mg} / 100 \mathrm{ml}$ solution SDS $)$.

Fourier-transform infrared spectroscopy (FTIR) spectra of graphite, GO, MGO and RGOHI- 
$\mathrm{AcOH}$ were observed on Figure 1A. Oxygen functional groups of powder GO showed stretching peaks at $1720 \mathrm{~cm}^{-1}(\mathrm{C}=\mathrm{O})$, and a broad band at $2431-3722 \mathrm{~cm}^{-1}$ (OH of hydrogen bonds) compared with graphite. After modification with PEG, the oxygen peaks of MGO were slightly lower than GO and decreased dramatically in the RGOHI-AcOH. This is the result of the restoration of the electronic conjugation within the platelets and proving the ability to preliminary reduction of PEG (with the groups of $\mathrm{OH}$ as a reducing agent [2]). The next, the ultraviolet-visible spectra (Figure 1B) of the GO dispersion in water shows strong absorption bands at $224 \mathrm{~nm}$ (from the $\pi$-plasmon of carbon), a shoulder peak at $300 \mathrm{~nm}$ (from the $\mathrm{n} \rightarrow \pi^{*}$ transitions of $\mathrm{C}=\mathrm{O}$ ) [13]. The peaks of $\mathrm{MGO}$ and RGOHI-AcOH moved to $260 \mathrm{~nm}$ and $266 \mathrm{~nm}$ respectively and corresponded to restoration of the electronic conjugation within $\mathrm{MGO}$ and RGOHI-AcOH layers.

Figure 2A shows the X-ray diffraction pattern of graphite, GO, MGO and RGOHI$\mathrm{AcOH}$. The GO is a larger interlayer spacing than that of graphite (GO: major peak at $2 \theta=11^{0}$ corresponding to an interlayer spacing of $7.792 \AA$ compared with graphite's major peak at 26.5 o corresponding to $3.33 \AA$ ) due to the oxygen functional groups and the water held in the interlayer galleries by the hydrogen bonds of GO. With MGO and RGOHI-AcOH, the major peaks $\left(2 \theta=11^{\circ}\right)$ is disappear in the XRD patterns corresponding to the breakdown of the crystal structure compared with graphite oxide. This proves that MGO and RGOHI-AcOH was exfoliated into individual platelets and then agglomerated into a powder form.
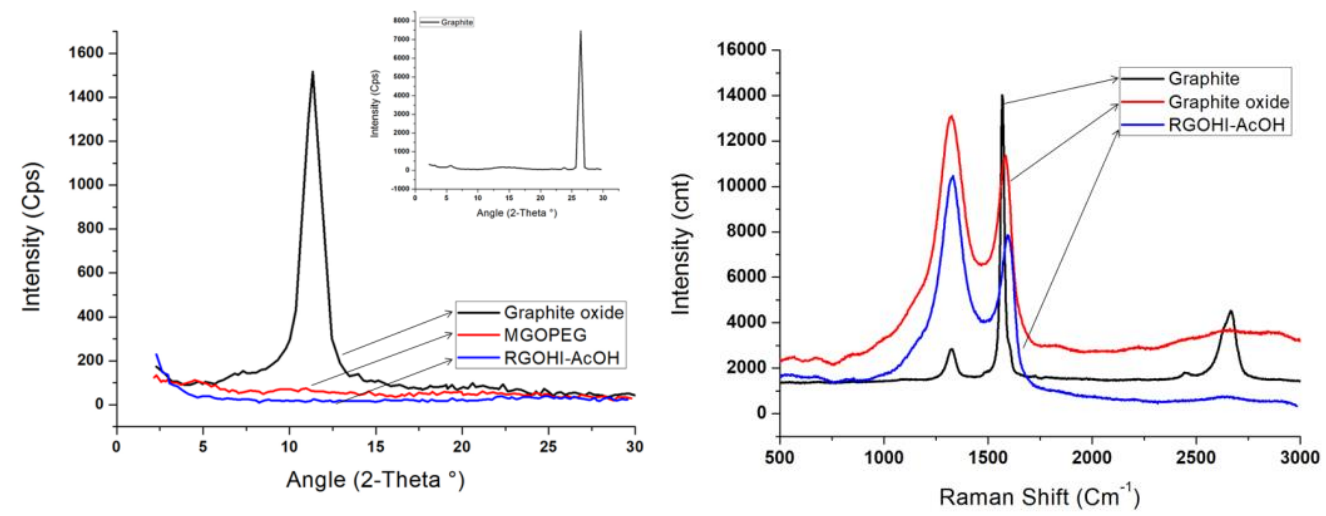

A

B

Figure 2. (A) Powder XRD patterns of graphite, GO, MGO and $\mathrm{RGO}_{\mathrm{HI}-\mathrm{AcOH}}$ and (B) Raman spectra of graphite, $\mathrm{GO}$ and $\mathrm{RGO}_{\mathrm{HI}-\mathrm{AcOH}}$

Figure 2B presents the Raman spectra of graphitic layers in the powder form. The peak for GO $\left(1586 \mathrm{~cm}^{-1}\right)$ at the G-band was compared with that of graphite $\left(1568 \mathrm{~cm}^{-1}\right)$. This was

attributed the presence of isolated double bonds that resonate at frequencies higher than that of the G-band of the graphite [13]. RGOHI-AcOH showed the peak of G-band at $1598 \mathrm{~cm}^{-1}$, which 
corresponds to the hard way to recover of the hexagonal network of carbon atoms with defects. The ID/IG ratio of RGOHI-AcOH (1.35) is higher than GO (1.23) and graphite (0.10). Cause of this result is the reduction process altered the structure of GO with a high quantity of structural defects [9]. The peak at 2D-band of RGOHI$\mathrm{AcOH}$ and GO are not clearly compared with the original graphite. This is a weakness of chemical ways to reduce graphite oxide.

Thermo gravimetric analysis (TGA, Figure 3B) graphs show weight profiles of powder samples as variation of temperature (heating rate, $20{ }^{\circ} \mathrm{C} / \mathrm{min}$ ) under $\mathrm{N}_{2}$ flow. Weight loss ( 8.5 wt. $\%$ ) of the GO up to $100{ }^{\circ} \mathrm{C}$ could be primarily

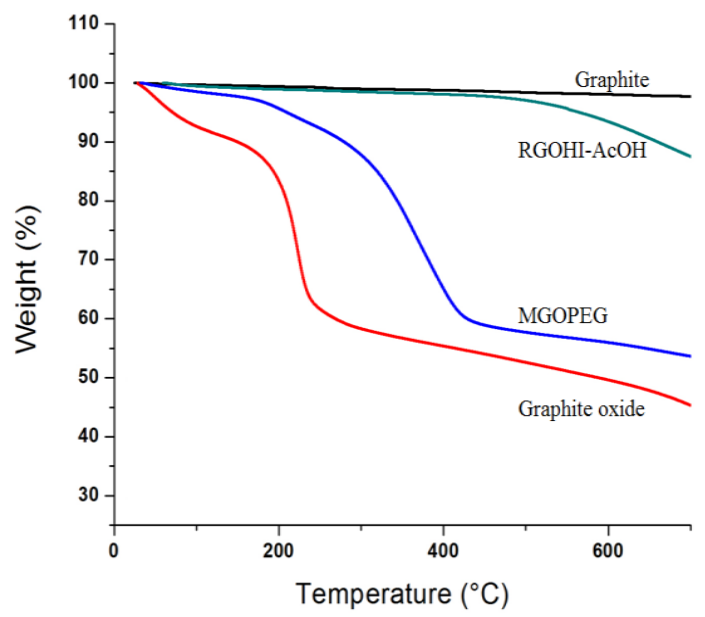

due to evaporation of water molecules held in the samples and this followed by loss of oxygen from the GO platelets themselves (such as by evolution of $\mathrm{CO}$ and $\mathrm{CO}_{2}$ from the sample) at slightly higher temperatures [13]. The modified $\mathrm{GO}$ is higher thermal stability than GO (the temperature of peak at $268{ }^{\circ} \mathrm{C}$ compared with 222 ${ }^{\circ} \mathrm{C}$ of GO) because of preliminary reduction of PEG mentioned above. $\mathrm{RGO}_{\mathrm{HI}-\mathrm{AcOH}}$ showed much higher thermal stability (weight loss of 13 wt.\% for $\mathrm{RGO}_{\mathrm{HI}-\mathrm{AcOH}}$ up to $700{ }^{\circ} \mathrm{C}$ ) and thermal behavior similar to graphite because of the better graphitization and deoxygenation of $\mathrm{RGO}_{\mathrm{HI}-\mathrm{AcOH}}$ with enhanced Van der Waals forces between layers [13].

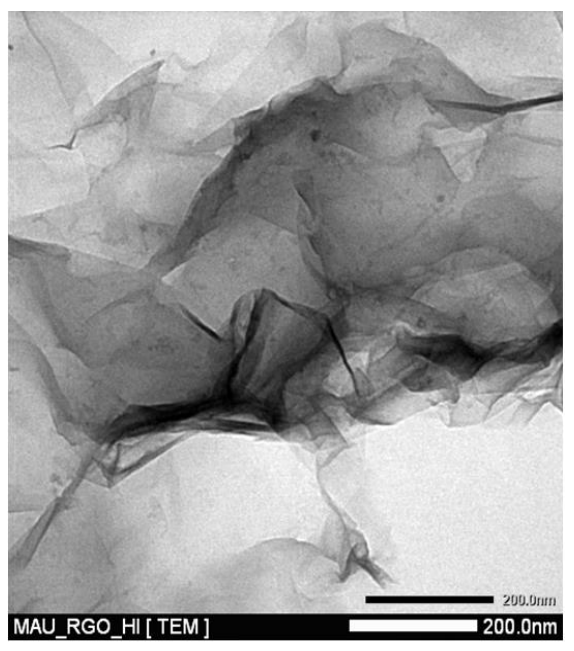

B

Figure 3. (A) Decomposition behavior of graphite GO, MGO and (B) RGOHI-AcOH and TEM images of RGOHI-AcOH

The Figure 3A show transmission electron microscopy (TEM) images of the platelets (dripping on the copper mesh substrate). The monolayers were observed next to multilayers of $\mathrm{RGO}_{\mathrm{HI}-\mathrm{AcOH}}$ dispersed in solution of $1 \mathrm{wt} \% \mathrm{SDS}$ 

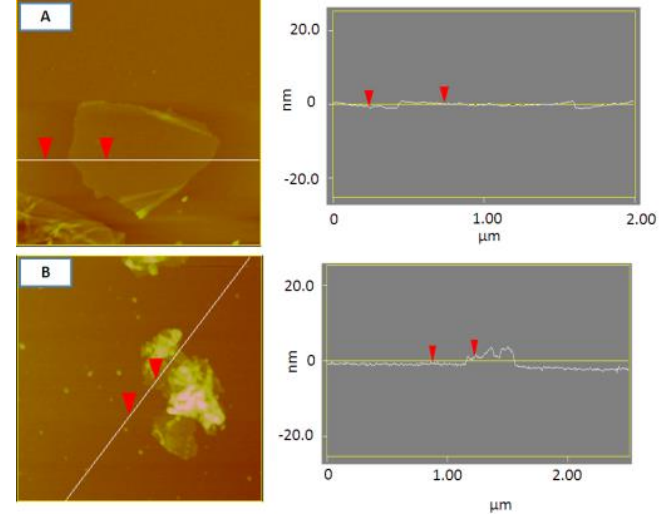

Figure 4. AFM images of MGO (A) and RGOHI$\mathrm{AcOH}(\mathrm{B})$

The AFM images of MGO (Figure 4A) showed the single-layer graphene oxide with thickness of $1.050 \mathrm{~nm}$ and diameter of about $1000 \mathrm{~nm}$. Besides, Figure 4B showed the morphology of RGOHI-AcOH with thickness of $1.605 \mathrm{~nm}$ and diameter of about $500 \mathrm{~nm}$.

This demonstrates that both $\mathrm{MgO}$ and RGO samples reached exfoliated structure. However, $\mathrm{RGOHI}-\mathrm{AcOH}$ is easier to agglomerate than $\mathrm{MGO}$ and RGOHI-AcOH is also be chopped under the effect of the reduction. The more reduction is strong, the more size of RGO is smaller. The conductivity and sheet resistance of the RGOHI-AcOH paper $(\sim 5,0 \mu \mathrm{m}$ thickness, Figure 5) was $1.66 \times 103$ S.m $^{-1}$ (electrical conductivity $=1 /($ thickness $\mathrm{x}$ sheet resistance $)$ and $120 \Omega /$ sq respectively while graphite oxide and MGO were non-conductive. The high conductivity of the RGOHI-AcOH was attributed to well restore electronic structure of layers exfoliated through the reduction.

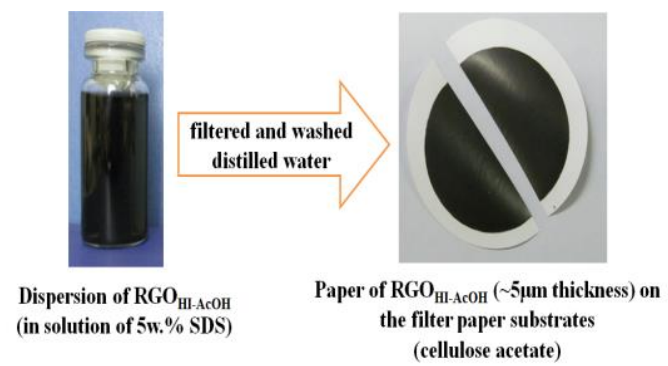

Figure 5. Fabrication process of RGOHI-AcOH paper by low pressure filtration method

\section{CONCLUSION}

We have succeeded in exfoliating GO to monolayer under the support of PEG as a modifier evidenced by XRD, TEM and AFM. $\mathrm{RGO}_{\mathrm{HI}-\mathrm{AcOH}}$ was high conductivity $(120 \Omega / \mathrm{sq})$ and good thermal properties showed by TGA curve. $\mathrm{RGO}_{\mathrm{HI}-\mathrm{AcOH}}$ can be applied in the fields of electronics, solar cells batteries and polymer nanocomposites.

ACKNOWLEDGMENTS: In order to complete this study, we gratefully acknowledge funding from the key projects (B2012-18-04TD) of Vietnam National University, Ho Chi Minh City (VNU-HCM). We gratefully acknowledge Applied Physical Chemistry Laboratory, (VNU-HCM) for the support of necessary equipment. 


\section{Tách bóc Graphit oxit và ứng dụng chế tạo Graphen bằng phương pháp hóa học}

\section{- Mai Thanh Tâm}

- Hà Thúc Chí Nhân

- Hà Thúc Huy

Trường Đại học Khoa học Tự nhiên, ĐHQG-HCM

TÓM TÁTT

Một hướng mới trong việc tách bóc graphit oxit dưới sự tán trợ của polyetylen oxit (PEO) và sóng siêu âm đã được tiến hành, Graphit oxit sau khi biến tính và tách bóc đơn lớp sẽ trở thành graphene oxit. Kết quả XRD cho thấy mũi kết tinh $d_{002}$ của $G O$ đã biến mất sau khi biến tính. Bên cạnh đó, ảnh TEM và AFM cũng xác định được đơn lớp graphene oxit với bề dày khoảng $1 \mathrm{~nm}$.

Graphene oxit được khử bằng hệ hai axit hydrolodic -axetic (HI-AcOH) tưong tư nhu Rodney S. Ruoff và đồng nghiệp. Điện trở mặt của màng $R G O_{H I-A c O H}$ trên đế xelulozo axetat được xác định khoảng $120 \Omega /$ sq. Thêm vào đó, phổ FTIR, UV-Vis và Raman còn cho thấy rõ hơn các tính chất của graphit oxit, graphen oxit và $R G O_{H I-A c O H}$.

Từ khoá: Graphen oxit, graphen, polyetylen oxit.

\section{REFERENCE}

[1]. D.R. Dreyer, C.W. Bielawski, R.S. Ruoff, The chemistry of graphene oxide, Chem. Soc. Rev, 39, 228-240 (2010).

[2]. D.R. Dreyer, S. Murali, Y. Zhu, R.S. Ruoff, C.W. Bielawski, Reduction of graphite oxide using alcohols, Journal of Materials Chemistry, 21, 3443 (2011).

[3]. E.C. Salas, Z. Sun, A. Luttge, J.M. Tour, Reduction of graphene oxide via bacterial respiration, AcS Nano, 4, 4852-4856 (2010).

[4]. A.A. Green, M.C. Hersam, Solution phase production of graphene with controlled thickness via density differentiation, Nano Lett., 9, 4031-4036 (2009).

[5]. H. Paul, D.M., Hydrazine reduced exfoliated graphene/graphene oxide layers and magnetoconductance measurements of $\mathrm{Ge}$ supported graphene layers, Appl Phys A, 103, 395-402 (2011).

[6]. W. Hummersjr, R. Offeman, Preparation of graphitic oxide, the baroid division nationalle adc ompany, 1339 (1958) .

[7]. I.K. Moon, J.L., R.S. Ruoff, H. Lee, Reduced graphene oxide by chemical graphitization, Nature Communications, 1, 1-6 (2010). 
[8]. L. Jung, M. Vaupel, M. Pelton, R. Piner, D.A. Dikin, S. Stankovich, J. An, R.S. Ruoff, Characterization of thermally reduced graphene oxide by imaging ellipsometry, $J$. Phys. Chem. C, 112, 8499-8506 (2008).

[9]. K.N. Kudin, B. Ozbas, H.C. Schniepp, R.K. Prud'homme, I.A. Aksay, R. Car, Raman spectra of graphite oxide and functionalized graphene sheets, Nano Letters, 8, 36-41 (2008).

[10]. Z. Liu, J. Robinson, X. Sun, H. Dai, PEGylated nanographene oxide for delivery of water-insoluble cancer drugs, Journal of the American Chemical Society, 130, 10876-10877 (2008) .

[11].Z. Liu, , J.T. Robinson, X. Sun, H. Dai, PEGylated nanographene oxide for delivery of water-insoluble cancer drugs, J.am. Chem. Soc. 130, 10876-10877, (2008).

[12]. M. Lotya, et al., Liquid phase production of graphene by exfoliation of graphite in surfactant/water solutions, J. Am. Chem. Soc. 131, 3611-3620 (2009).

[13]. I.K. Moon, , J. Lee, R.S. Ruoff, H. Lee, Reduced graphene oxide by chemical graphitization, Nature Communications, 1 , 1-6 (2010).

[14]. K.S. Novoselov, , A.K. Geim, S.V. Morozov, D. Jiang, Y. Zhang, S.V. Dubonos, Grigorieva, A.A. Firsov, Electric field effect in atomically thin carbon films, Science, 306, 666-669 (2004)

[15]. Z. Osváth, A. Darabont, P. Nemes-Incze, E. Horváth, Z.E. Horváth, L.P. Biró, Graphene layers from thermal oxidation of exfoliated graphite plates, Carbon, 45, 3022-3026 (2007).
[16]. S. Park, R.S. Ruoff, Chemical methods for the production of graphenes, Nature Nanotechnology, 4, 217-224 (2009).

[17]. P. Zhu, M., ShuhuaXiao, DongZhang Experimental study on the reducibility of graphene oxide byhydrazine hydrate, Physica B , 406, 498-502 (2011).

[18]. Y. Ren, et al., An improved method for transferring graphene grown by chemical vapor deposition, Nano, 07, 1-6 (2012).

[19]. V.Singh, , D. Joung, L. Zhai, S. Das, S.I. Khondaker, S. Seal, Graphene based materials: Past, present and future, Progress in Materials Science, 56, 1178-1271 (2011).

[20]. S. Stankovich, R. Piner, S. Nguyen, R. Ruoff, Synthesis and exfoliation of isocyanate- treated graphene oxide nanoplatelets, Carbon, 44, 3342-3347 (2006).

[21]. S. Park, J.A. J.R. Potts, A. Velamakanni, S. Murali, R.S. Ruoff, Hydrazine-reduction graphite- and graphene oxide, Carbon, 301 9-302 (2011).

[22]. X. Zheng, Q.X., L. He, N. Yu, S. Wang, Z. Chen, J.W. Fu, Modification of graphene oxide with amphiphilic double - crystalline block copolymer polyethylene - b - poly (ethylene oxide) with assistance of supercritical $\mathrm{CO} 2$ and its further functionalization, J. Phys. Chem. B, 115, 5815-5826 (2011).

[23]. K. Yang, J. Wan, S. Zhang, Y. Zhang, S.-T. Lee, Z. Liu, In vivo pharmacokinetics, longterm biodistribution, and toxicology of EGylated graphene in mice, AcS Nano, 5, 516-522 (2011). 